\title{
Cariostatic effect of fluoride-containing restorative materials associated with fluoride gels on root dentin
}

\author{
Fernanda Tavares BORGES ${ }^{1}$, Wagner Reis da Costa CAMPOS ${ }^{2}$, Lais Sant'ana MUNARI ${ }^{3}$, Allyson Nogueira \\ MOREIRA ${ }^{4}$, Saul Martins PAIVA ${ }^{5}$, Claudia Silami MAGALHÃES ${ }^{6}$
}

\begin{abstract}
1- DDS, Graduate student, Department of Restorative Dentistry, School of Dentistry, Federal University of Minas Gerais, Belo Horizonte, MG, Brazil. 2- Metallurgist Engineer, PhD, Center of Nuclear Technology Development, Belo Horizonte, MG, Brazil.

3- Graduate student, Department of Restorative Dentistry, School of Dentistry, Federal University of Minas Gerais, Belo Horizonte, MG, Brazil.

4- DDS, PhD, Associate Professor, Department of Restorative Dentistry, School of Dentistry, Federal University of Minas Gerais, Belo Horizonte, MG, Brazil. 5- DDS, MS, PhD, Associate Professor, Department of Pediatric Dentistry and Orthodontics, School of Dentistry, Federal University of Minas Gerais, Belo Horizonte, MG, Brazil.

6- DDS, MS, PhD, Associate Professor, Department of Restorative Dentistry, School of Dentistry, Federal University of Minas Gerais, Belo Horizonte, MG, Brazil.
\end{abstract}

Corresponding address: Claudia Silami Magalhães - Rua Ludgero Dolabela, 139 / 301 - Bairro Gutierrez - 30-430130 - Belo Horizonte - MG - Phone / Fax: 3133321784 / 34092430 - e-mail:silamics@yahoo.com

Received: March 6, 2009 - Modification: March 25, 2010 - Accepted: May 21, 2010

\section{ABSTRACT}

Secondary caries is still the main cause of restoration replacement, especially on the root surface Objective: This in vitro study evaluated the cariostatic effects of fluoride-containing restorative materials associated with fluoride gels, on root dentin. Materials and Methods: A randomized complete block design was used to test the effects of the restorative systems, fluoride regimes and the interactions among them at different distances from restoration margins. Standardized cavities were prepared on 240 bovine root specimens and randomly assigned to 15 groups of treatments $(n=16)$. Cavities were filled with the following restorative materials: Ketac-Fil (3M-ESPE); Vitremer (3M-ESPE); Dyract/Prime \& Bond NT (Dentsply); Charisma/Gluma One Bond (Heraeus Kulzer) and the control, Z250/Single Bond (3M-ESPE). The specimens were subjected to a $\mathrm{pH}$-cycling model designed to simulate highcaries activity. During the cycles, $1.23 \%$ acidulated phosphate fluoride, $2.0 \%$ neutral sodium fluoride or deionized/distilled water (control) was applied to the specimens for $4 \mathrm{~min}$. The surface Knoop microhardness test was performed before $\left(\mathrm{KHN}_{\mathrm{i}}\right)$ and after $\left(\mathrm{KHN}_{\mathrm{f}}\right)$ the $\mathrm{pH}$ cycles at 100, 200 and 300 $\mu \mathrm{m}$ from the margins. Dentin microhardness loss was represented by the difference in initial and final values $\left(\mathrm{KHN}_{\mathrm{i}}-\mathrm{KHN}_{\mathrm{f}}\right)$. Data were analyzed by Friedman's and Wilcoxon's tests, ANOVA and Tukey's test $(\alpha=5 \%)$. Results: The interaction of restorative systems and topical treatments was not significant $(p=0.102)$. Dentin microhardness loss was lowest closer to the restoration. Ketac-fil presented the highest cariostatic effect. Vitremer presented a moderate effect, while Dyract and Charisma did not differ from the control, Z250. The effects of neutral and acidulated fluoride gels were similar to each other and higher than the control. Conclusion: Conventional and resin-modified glass ionomer cements as well as neutral and acidulated fluoride gels inhibit the progression of artificial caries adjacent to restorations. The associated effect of fluoride-containing restorative materials and gels could not be demonstrated.

Key words: Fluorides. Dental restoration. Dental caries.

\section{INTRODUCTION}

Increased life expectancies, improvements in lifestyle and the intensification of preventive interventions have all contributed towards a longer retention of natural teeth in old age. Exposed root surfaces are common in adults and older populations, generally due to gingival recession, which is associated with anatomical factors, microbially induced periodontal diseases, surgical periodontal therapies, orthodontic movement of the teeth and various forms of trauma ${ }^{14,16}$. Exposed dentin on root surfaces becomes more susceptible to caries than enamel because of its low mineral content and its higher critical $\mathrm{pH}$ for dissolution ${ }^{8,14}$.

Preventive management of primary root caries lesions has a better long-term prognosis than restorative treatment. Monitoring noncavitated 
lesions and reinforcing prophylactic programs must be always the choice for stopping caries progression ${ }^{8,14}$. However, when the dental anatomy and function are involved, is necessary to institute restorative treatments using materials with adequate strength, esthetics, adhesive and cariostatic effects ${ }^{8}$.

Secondary caries has been shown in studies worldwide to be the most common reason for the replacement of all types of restorations, regardless of the material used ${ }^{18,19}$. Secondary caries occur mainly at the cervical margin of restoration, where optimum hygiene conditions are difficult, and restorative techniques are sensitive and complicated by the lack of an excellent adhesion to dentin ${ }^{19}$.

Conventional glass ionomer cements (GICs), resin-modified GICs (RMGICs) and fluoridereleasing composite resins could be indicated for the restoration of root caries cavities ${ }^{8,30}$. Previous studies have suggested that the release of fluoride from a fluoride-containing material may prevent the formation of wall lesions and prevent caries at the margins of restorations ${ }^{10,12,24,28}$. The mechanisms involved in the anticariogenic effects of fluoride include the reduction of demineralization, the enhancement of remineralization ${ }^{5,6,15}$, the interference of pellicle and plaque formation and the inhibition of microbial growth and metabolism ${ }^{21,30}$.

In vitro studies have demonstrated the synergic effect of restorative materials in association with topical fluoride rinses or dentifrice to prevent caries adjacent to the restorations ${ }^{11,24}$. Professional topical fluoride has been widely used to control the activity of caries lesions. A fluoride therapy based on daily use of fluoride gels during teethbrushing has been suggested, especially for the treatment of caries-active patients. This could add the benefit of a product with anticariogenic abilities, to the low cost and short operational time of self-applied procedures ${ }^{6,15}$. Therefore, we hypothesized that there may be an additional effect of fluoride at high concentrations on the loss of dentin microhardness around fluoride-containing restorative materials. This in vitro study compared the cariostatic effects of 5 restorative materials a conventional GIC, a RMGIC, a polyacid-modified composite resin, a resin composite with fluoride, and a resin composite without fluoride - associated with the use of neutral or acidulate fluoride gels on artificial secondary caries on root dentin. This study investigated whether there was any difference in dentin microhardness loss around fluoridecontaining restorative materials, associated with topical fluoride treatments, at different distances from the restoration margins.

\section{MATERIAL AND METHODS}

\section{Experimental Design}

A randomized complete block design was used to evaluate the cariostatic effects of fluoridecontaining restorative materials associated with use of fluoride gels on root dentin. Blocking was a strategy used to control the variability of the dentin substrate. By using this design, the specimens formed a more homogeneous experimental unit on which to compare the treatments ${ }^{20}$. "Randomized complete" indicates that each block contains all of the treatments, applied according the randomly determined order.

The factors studied were: restorative material at 5 levels (Figure 1), topical treatments at 3 levels (Figure 1) and distance from the restoration margins at 3 levels (100, 200 and $300 \mathrm{~mm}$ ). The experimental units were 240 bovine root specimens randomly assigned to 15 groups of treatments $(n=16)$. Each block contained each one of all possible combinations of 5 (restorative system) $\times 3$ (fluoride regime) groups of treatments (Figure 2). The control group of restorative system was a composite resin without fluoride (Z250, 3M ESPE Dental Products, Sumaré, SP, Brazil). Control group of topical treatments was distilled/deionized water. Acidulated fluoride gel, neutral fluoride gel and water were applied to the restoration and adjacent dentin to test the associated effect of restorative materials and gels.

The restorative materials and topical treatments were applied according to the order randomly determined by Microsoft Excel ${ }^{\circledR}$ software. The dependent variable was the Knoop microhardness (KHN) loss of root dentine around the restorations.

\section{Preparation of specimens}

Two hundred and forty incisors were extracted from bovine jaws immediately after butchering. The teeth were thoroughly scaled, polished with pumice/water slurry, and washed with distilled water to clean them from debris, and were kept in a $1 \%$ chloramine-T solution for 1 week.

The roots were separated from crows and axially hemi-sectioned in a mesiodistal direction. Sections $(5.0 \mathrm{~mm} \times 5.0 \mathrm{~mm} \times 2.0 \mathrm{~mm}$ ) were obtained from the buccal or the lingual root surfaces at $3.0 \mathrm{~mm}$ from the cementonamel junction using a doublefaced diamond disc (KG Sorensen Ind. e Com. Ltda, Barueri, SP, Brazil) in a low-speed handpiece under water spray coolant. Each section was embedded in epoxy resin and ground flat with a water-cooled mechanical grinder (Polipan-U, Panambra, São Paulo, SP, Brazil) with \#400- and \#600-grit $\mathrm{Al}_{2} \mathrm{O}_{3}$ abrasive papers (Norton Abrasivos, Guarulhos, SP, Brazil).

\section{Cavity preparation and restorative procedures}

A standard cylindrical-shaped cavity $(1.5 \mathrm{~mm}$ depth and $2.0 \mathrm{~mm}$ in diameter) was prepared at the center of the flattened dentin surface using a \#2294 diamond bur (KG Sorensen Ind. e Com. Ltda, Barueri, SP, Brazil) in a high-speed 


\begin{tabular}{|c|c|c|}
\hline Restorative system / Topical treatment & Manufacturer & Batch number \\
\hline $\begin{array}{l}\text { Ketac-Fil } \\
\text { Glass-ionomer cement }\end{array}$ & $\begin{array}{l}\text { 3M ESPE Dental Products } \\
\text { (Sumaré, SP, Brazil) }\end{array}$ & $\begin{array}{l}\text { Powder: } 142152 \\
\text { Liquid: } 135132\end{array}$ \\
\hline $\begin{array}{l}\text { Vitremer } \\
\text { Resin modified glass-ionomer }\end{array}$ & $\begin{array}{l}\text { 3M ESPE Dental Products } \\
\text { (Sumaré, SP, Brazil) }\end{array}$ & $\begin{array}{l}\text { Powder: } 20011019 \\
\text { Liquid: } 20011025 \\
\text { Primer: } 20010928 \\
\text { Glaze: } 20011031\end{array}$ \\
\hline $\begin{array}{l}\text { Dyract-Prime \& Bond NT } \\
\text { Polyacid modified composite resin }\end{array}$ & $\begin{array}{l}\text { Dentsply Caulk } \\
\text { (Milford, DE, USA) }\end{array}$ & $\begin{array}{l}\text { Dyract: } 0108000442 \\
\text { Prime \& Bond NT: } 3708\end{array}$ \\
\hline $\begin{array}{l}\text { Charisma-GLUMA One Bond } \\
\text { Fluoride composite resin }\end{array}$ & $\begin{array}{l}\text { Heraeus Kulzer - GmbH (Gonsennheumer, } \\
\text { Mainz, Germany) }\end{array}$ & $\begin{array}{l}\text { Charisma: } 060044 \\
\text { GLUMA One Bond: } 195001\end{array}$ \\
\hline $\begin{array}{l}\text { Filtek Z250-Single Bond } \\
\text { Non-Fluoride composite resin (control) }\end{array}$ & $\begin{array}{l}\text { 3M ESPE Dental Products } \\
\text { (Sumaré, SP, Brazil) }\end{array}$ & $\begin{array}{l}\mathrm{Z} 2502 \mathrm{XM} \\
\text { Single Bond } 1105\end{array}$ \\
\hline $1.23 \%$ Acidulated Phosphate Fluoride gel & $\begin{array}{c}\text { Vigodent } \\
\text { (Rio de Janeiro, RJ, Brazil) }\end{array}$ & - \\
\hline $2 \%$ Neutral Sodium Fluoride gel & $\begin{array}{c}\text { Vigodent } \\
\text { (Rio de Janeiro, RJ, Brazil) }\end{array}$ & - \\
\hline Deionized/distilled water (control) & - & - \\
\hline
\end{tabular}

Figure 1- The restorative materials and topical treatments applied to the specimens

\begin{tabular}{|cl|}
\hline Groups & Restorative Materials and Topical Treatments \\
\hline 1 & Ketac-Fil $+1.23 \%$ Acidulated Phosphate Fluoride gel \\
2 & Ketac-Fil $+2 \%$ Neutral Sodium Fluoride gel \\
3 & Ketac-Fil + Deionized/distilled water \\
4 & Vitremer + 1.23\% Acidulated Phosphate Fluoride gel \\
5 & Vitremer + 2\% Neutral Sodium Fluoride gel \\
6 & Vitremer + Deionized/distilled water \\
7 & Dyract $+1.23 \%$ Acidulated Phosphate Fluoride gel \\
8 & Dyract $+2 \%$ Neutral Sodium Fluoride gel \\
9 & Dyract + Deionized/distilled water \\
10 & Charisma + 1.23\% Acidulated Phosphate Fluoride gel \\
11 & Charisma $+2 \%$ Neutral Sodium Fluoride gel \\
12 & Charisma + Deionized/distilled water \\
13 & Filtek Z250 + 1.23\% Acidulated Phosphate Fluoride gel \\
14 & Filtek Z250 + 2\% Neutral Sodium Fluoride gel \\
15 & Filtek Z250 + Deionized/distilled water \\
\hline
\end{tabular}

Figure 2- Groups of restorative materials and topical treatments assigned within each block 
handpiece under a constant water-spray coolant. The prepared cavities were treated in the following manner, according to each restorative material:

Ketac-Fil (3M ESPE): 10\% polyacrylic acid was spread over the cavity for $10 \mathrm{~s}$, rinsed for $30 \mathrm{~s}$, and gently air-dried for 5 s, avoiding desiccation. KetacFil powder and Ketac-Fil liquid were dispensed at 3.2:1 by weight, hand-mixed within $60 \mathrm{~s}$, loaded into a syringe (Centrix, DFL Ind. e Com. SA, Rio de Janeiro, RJ, Brazil), and injected into the preparation. Then, the surface was covered with a polyester strip and a glass slab and pressed with a weight of $1,000 \mathrm{~g}$ for $30 \mathrm{~s}$ to extrude any excess. Seven minutes after the beginning of the mixture, the strip was removed and a surface protector (Ketac Glaze, 3M ESPE) was immediately applied and light-cured for $20 \mathrm{~s}$.

Vitremer (3M ESPE): Vitremer primer was applied to the cavity preparation for $30 \mathrm{~s}$, air-dried for $15 \mathrm{~s}$ and light-cured for $20 \mathrm{~s}$. Vitremer powder and Vitremer liquid were dispensed at $2.5: 1$ by weight, hand-mixed within $45 \mathrm{~s}$, loaded into a Centrix syringe, and injected into the preparation. Then, the surface was covered with a polyester strip and a glass slab and pressed with a weight of $1,000 \mathrm{~g}$ for $30 \mathrm{~s}$ to extrude any excess. The restoration was light cured for $40 \mathrm{~s}$, the strip was removed and Vitremer finishing gloss was applied and light-cured for $20 \mathrm{~s}$.

Dyract/Prime \& Bond NT (Dentsply Caulk, Milford, DE, USA): $35 \%$ phosphoric acid was applied to the cavity for $15 \mathrm{~s}$ and rinsed for $30 \mathrm{~s}$. Excess water was blotted using absorbent paper. One coat of Prime \& Bond NT was applied to the cavity, left undisturbed for $30 \mathrm{~s}$, blown with air for $5 \mathrm{~s}$, and light-cured for $10 \mathrm{~s}$. Dyract was injected into the cavity preparation, covered with a polyester strip and a glass slab, pressed with a weight of $1,000 \mathrm{~g}$ for $30 \mathrm{~s}$ to extrude any excess and light cured for $40 \mathrm{~s}$.

Charisma/GLUMA One Bond (Heraeus Kulzer, Gonsennheumer, Mainz, Germany): 20\% phosphoric acid was applied to the cavity for 20 $\mathrm{s}$ and rinsed for $40 \mathrm{~s}$. Excess water was blotted using absorbent paper. Two consecutive coats of adhesive were applied, gently air-dried for $5 \mathrm{~s}$ and light-cured for $20 \mathrm{~s}$. The bonded cavity was bulkfilled with Charisma, covered with a polyester strip and a glass slab and pressed with a weight of 1,000 $g$ for $30 \mathrm{~s}$ to extrude any excess. After removal of the slab, the restoration was light-cured for $20 \mathrm{~s}$.

Z250/Single Bond (3M ESPE): 35\% phosphoric acid was applied to the cavity for $15 \mathrm{~s}$ and rinsed for $10 \mathrm{~s}$. Excess water was blotted using absorbent paper. Immediately after blotting, 2 consecutive coats of adhesive were applied for 15 s with gentle agitation using a fully saturated applicator. After removal of the solvent by brief air-drying for $5 \mathrm{~s}$, the adhesive was light-cured for $10 \mathrm{~s}$. The bonded cavity was bulk-filled with Z250, covered with a polyester strip and a glass slab and pressed with a weight of $1,000 \mathrm{~g}$ for $30 \mathrm{~s}$ to extrude any excess. After removal of the slab, the restoration was lightcured for $20 \mathrm{~s}$.

The materials were light-cured using a halogen light-curing unit (XL300, 3M Dental Products, St. Paul, MN, USA) with an irradiance of $500 \mathrm{~mW} / \mathrm{cm}^{2}$.

The specimens were stored in $100 \%$ relative humidity for $24 \mathrm{~h}$ at $37 \pm 1^{\circ} \mathrm{C}$. Then, excess restorative material was removed using a watercooled mechanical grinder (Polipan-U) with \#1000grit $\mathrm{Al}_{2} \mathrm{O}_{3}$ abrasive paper (Norton Abrasivos). The restored fragments were cleaned with deionized/ distilled water in an ultrasonic bath for $6 \mathrm{~min}$ in order to remove remnants of polishing debris.

\section{pH-Cycling model}

In order to standardize the dentin area exposed to the $\mathrm{pH}$-cycling, the specimens were entirely covered with dental wax (Herpo Produtos Dentários Ltda, Rio de Janeiro, RJ, Brazil), leaving exposed only the restorations and $2.0 \mathrm{~mm}$ around their margins.

Each specimen was individually subjected to a demineralization/remineralization dynamic model, similar to that proposed by Featherstone, et al. ${ }^{9}$ (1986) and modified by Serra and Cury ${ }^{26}$ (1992), simulating in vivo high caries activity conditions. Initially, each specimen was immersed in $5 \mathrm{~mL}$ remineralizing solution $\left(\mathrm{Ca}^{+2} 1.5 \mathrm{mmol} / \mathrm{L}, \mathrm{PO}_{4}^{-3} 0.9\right.$ $\mathrm{mmol} / \mathrm{L}, \mathrm{KCl} 150 \mathrm{mmol} / \mathrm{L}$, Tris[hydroxyme2sthyl] aminomethane $2.0 \mathrm{mmol} / \mathrm{L}$ at $\mathrm{pH}$ 7.0) for $24 \mathrm{~h}$. After, the specimens were washed in deionized/ distilled water and immersed individually, in $5 \mathrm{~mL}$ demineralizing solution $\left(\mathrm{Ca}^{+2} 2.0 \mathrm{mmol} / \mathrm{L}, \mathrm{PO}_{4}^{-3}\right.$ $2.0 \mathrm{mmol} / \mathrm{L}$ in a buffer solution of $0.075 \mathrm{mmol} / \mathrm{L}$ of $\mathrm{CH}_{3} \mathrm{COO}^{-}$at $\mathrm{pH} 4.3$ ) for $1 \mathrm{~h}$. After rinsing with deionized/distilled water, $1.23 \%$ acidulated phosphate fluoride $(0.03 \mathrm{~mL}), 2.0 \%$ neutral sodium fluoride $(0.03 \mathrm{~mL})$ or deionized/distilled water $(0.03$ $\mathrm{ml}$ ) was applied to the restoration and $2.0 \mathrm{~mm}$ around its margins for $4 \mathrm{~min}$. Then, the specimens were immersed in $5 \mathrm{~mL}$ of remineralizing solution, completing the 24-h cycle. Each $\mathrm{pH}$-cycle totaled $24 \mathrm{~h}$ (demineralization: $1 \mathrm{~h}$; topical treatment: $4 \mathrm{~min}$; remineralization: about $23 \mathrm{~h}$ ). Three $\mathrm{pH}$ cycling runs were completed during 3 consecutive days. The demineralizing and remineralizing solutions were renewed daily ${ }^{11}$.

\section{Surface Knoop microhardness measurements}

Dentin surface microhardness measurements were obtained using a microhardness tester (Durimet, Ernst Leitz GmbH, Wetzlar, Germany) with a Knoop diamond and a 5 g-static-load applied for $30 \mathrm{~s}^{1}$. The surface microhardness values were measured before and after the demineralization/ remineralization cycles. Nine initial indentations $\left(\mathrm{KHN}_{\mathrm{i}}\right)$ were made at three positions: $0^{\circ}, 60^{\circ}$ and $120^{\circ}$; and 9 final indentations $\left(\mathrm{KHN}_{\mathrm{f}}\right)$ were made at positions $180^{\circ}, 240^{\circ}$ and $300^{\circ}$ on dentin around the 
restoration. In each position, parallel indentations were made 100, 200 and $300 \mathrm{~mm}$ from the margin of the restoration ${ }^{11}$. The KHN values were calculated using the following equation:

$\mathrm{KHN}=(14229 . \mathrm{P}) / \mathrm{L}^{2}$

where $P$ is the applied load $(g)$ and $L$ is the indentation length $(\mathrm{mm})$.

\section{Statistical analysis}

For each specimen, the mean of the nine initial indentations $\left(\mathrm{KHN}_{\mathrm{i}}\right)$ and the mean of the nine final indentations $\left(\mathrm{KHN}_{\mathrm{f}}\right)$ were considered for statistical analysis. The difference between the initial and final microhardness values $\left(\mathrm{KHN}_{\mathrm{i}}-\mathrm{KHN}_{\mathrm{f}}\right)$ was used to represent superficial microhardness loss on root dentin. The statistical analysis considered the mean difference between the initial and final microhardness values for each association of material and treatment at 100, 200 and $300 \mathrm{~mm}$ distances.

The effect of distance on root dentin microhardness loss was evaluated by Friedman's and Wilcoxon's tests $(\alpha=0.05)$. An analysis of variance (ANOVA) tested the effects of blocking, the restorative systems, the topical treatments and their interactions for each level of the factor distance. A multiple-comparison Tukey's test $(\alpha=0.05)$ identified possible differences in the means of microhardness values. The software SPSS 8.0 (SPSS Inc., Chicago, IL, USA) was used for the analysis.

\section{RESULTS}

A Friedman's test showed statistically significant differences among the three levels of the factor distance $(p=0.007)$. There was a significant difference between the loss of dentin microhardness at 100 and $300 \mathrm{~mm}$. (Table 1 ).

ANOVA revealed a significant effect of the factors blocking $(p=0.000)$, the restorative system $(p=0.000)$ and topical treatment $(p=0.000)$ on the surface microhardness loss at 100, 200 and $300 \mathrm{~mm}$. The interaction of particular interest (restorative system $x$ topical treatment) was not significant at the distances of $100(p=0.102)$, $200(p=0.849)$ and $300 \mathrm{~mm}(p=0.580)$. As this interaction was not significant, factors were analyzed separately.

There were significant differences among the restorative systems at $100(p=0.000), 200$ $(p=0.000)$ and $300(p=0.000) \mathrm{mm}$ (Table 2). At a distance of $100 \mathrm{~mm}$, microhardness loss around Ketac-Fil was significantly lower than for the other restorative systems (Vitremer, Charisma, Dyract and Z250). The highest microhardness loss was observed in the non-fluoridated control material (Z250), which was similar to Charisma and Dyract. Vitremer showed a cariostatic effect lower than that of Ketac-fil, but higher than that of Dyract and Z250. At the distance of $200 \mathrm{~mm}$, the effect of the restorative system was similar to that shown at 100 $\mathrm{mm}$, but Vitremer did not differ significantly from

Table 1- Medians of the differences between initial and final dentin microhardness $\left(\mathrm{KHN}_{\mathrm{i}}-\mathrm{KHN}_{\mathrm{f}}\right)$, minimum and maximum values, considering all of the restorative systems and treatments at 100,200 and $300 \mathrm{~mm}$ distances

\begin{tabular}{cc}
\hline Distance from restoration margin $(\mathbf{m m})$ & $\mathrm{KHN}_{\mathrm{i}}-\mathrm{KHN}_{\mathbf{f}}(\mathbf{m i n} / \mathbf{m a x})$ \\
\hline & \\
\hline 200 & $19.39^{\mathrm{a}} \pm(-12.77 / 53.30)$ \\
300 & $19.53^{\mathrm{ab}} \pm(-13.09 / 54.93)$ \\
\hline
\end{tabular}

Statistical differences are expressed by different superscript letters $(p<0.05)$

Table 2- Means of the differences between initial and final dentin microhardness $\left(\mathrm{KHN}_{\mathrm{i}}-\mathrm{KHN}_{\mathrm{f}}\right)$ for the restorative systems evaluated at distances of 100,200 and $300 \mathrm{~mm}$

\begin{tabular}{lccc}
\hline Restorative System & \multicolumn{3}{c}{ Means of $\mathrm{KHN}_{\mathrm{i}}-\mathrm{KHN}_{\mathrm{f}} \pm$ (dp) } \\
\hline & $\mathbf{1 0 0} \mathbf{~ m m}$ & $\mathbf{2 0 0} \mathbf{~ m m}$ & $\mathbf{3 0 0} \mathbf{~ m m}$ \\
Ketac-Fil & $12.1^{\mathrm{a}} \pm(9.33)$ & $13.74^{\mathrm{a}} \pm(9.56)$ & $15.26^{\mathrm{a}} \pm(9.73)$ \\
Vitremer & $18.77^{\mathrm{b}} \pm(10.53)$ & $19.48^{\mathrm{b}} \pm(11.39)$ & $19.48^{\mathrm{ab}} \pm(10.93)$ \\
Charisma & $22.36^{\mathrm{bc}} \pm(12.14)$ & $23.09^{\mathrm{bc}} \pm(13.11)$ & $23.98^{\mathrm{bc}} \pm(11.83)$ \\
Dyract & $23.63^{\mathrm{c}} \pm(12.52)$ & $23.59^{\mathrm{bc}} \pm(12.36)$ & $22.84^{\mathrm{bc}} \pm(12.44)$ \\
Z250 & $23.77^{\mathrm{c}} \pm(10.35)$ & $24.16^{\mathrm{c}} \pm(9.96)$ & $24.06^{\mathrm{c}} \pm(9.48)$ \\
\hline
\end{tabular}

Means followed by distinct letters are different when compared in columns $(p<0.05)$

Tukey dms $(100 \mathrm{~mm})=4.41$; Tukey dms $(200 \mathrm{~mm})=4.61$; Tukey dms $(300 \mathrm{~mm})=4.41$ 
Table 3- Means of the differences between initial and final dentin microhardness $\left(\mathrm{KHN}_{\mathrm{i}}-\mathrm{KHN}_{\mathrm{f}}\right)$ for the topical treatments at the distances of 100,200 and $300 \mathrm{~mm}$

\begin{tabular}{lccc}
\hline Topical Treatment & \multicolumn{3}{c}{ Means of $\left(\mathrm{KHN}_{\mathrm{i}}-\mathrm{KHN}_{\mathrm{f}}\right) \pm(\mathrm{dp})$} \\
\hline & $\mathbf{1 0 0} \mathbf{~ m m}$ & $\mathbf{2 0 0} \mathbf{~ m m}$ & $\mathbf{3 0 0} \mathbf{~ m m}$ \\
Neutral & $17.73^{\mathrm{a}} \pm(11.14)$ & $18.53^{\mathrm{a}} \pm(11.56)$ & $19.23^{\mathrm{a}} \pm(11.33)$ \\
Acidulate & $19.16^{\mathrm{a}} \pm(10.28)$ & $18.81^{\mathrm{a}} \pm(10.63)$ & $18.99^{\mathrm{a}} \pm(10.10)$ \\
Control & $23.99^{\mathrm{a}} \pm(11.51)$ & $25.08^{\mathrm{b}} \pm(11.64)$ & $24.86^{\mathrm{b}} \pm(11.20)$ \\
\hline
\end{tabular}

Means followed by distinct letters are different when compared in columns $(p<0.05)$

Tukey dms $(100 \mathrm{~mm})=2.94$; Tukey dms $(200 \mathrm{~mm})=3.06$; Tukey dms $(300 \mathrm{~mm})=2.94$

Charisma and Dyract. At the distance of $300 \mathrm{~mm}$, Ketac-Fil showed a significantly higher cariostatic effect than for all other tested materials except for Vitremer, from which it did not differ. Vitremer showed a cariostatic effect higher than Z250, but similar to Charisma and Dyract.

Neutral and acidulate fluoride gels did not differ significantly and showed higher cariostatic effects than the control group for all the restorative systems and distances evaluated $(p=0.000)$ (Table 3).

\section{DISCUSSION}

The cariostatic effect of fluorides is well supported by the literature. Fluorides affect caries formation through a variety of mechanisms involving the reduction of demineralization, the enhancement of remineralization, the interference of pellicle and plaque formation and the inhibition of microbial growth and metabolism $5,6,15,21$. Fluoride release from restorative materials is related to their matrices, setting mechanisms and fluoride content and depends on the environmental conditions ${ }^{3,4,7,29,30}$.

After topical fluoride application (>100 ppm F), loosely bound fluoride or a calcium fluoride-like material is formed. Depending on the $\mathrm{pH}$ of the plaque fluid, this $\mathrm{CaF}_{2}$ layer, which has a higher solubility than hydroxyapatite and fluorapatite, will be dissolved, releasing fluoride to react with calcium and phosphate ions. The products of these reactions may be fluorapatite crystals or $\mathrm{CaF}_{2}$ incorporated on tooth surface. This reservoir of fluoride ions is available to inhibit demineralization and enhance remineralization ${ }^{5,15}$.

In this study, the differences on cariostatic effect could be attributed to the amount of fluoride released from the restorative materials, as evaluated by dentin microhardness loss at various distances from restoration margins. Although it was not able to completely inhibit microhardness loss adjacent to the restoration, Ketac-Fil exhibited the lowest loss due to its higher fluoride-releasing properties. GIC success in reducing the production of caries-like lesions in the adjacent root surface corroborates the results obtained by other in vitro studies ${ }^{10,11,12,24,28}$. Typical GICs are materials comprised of a calcium fluoro-alumino-silicate glass powder and an aqueous solution of a poly(acrylic acid-itaconic acid) copolymer containing tartaric acid $^{22}$. It is well known that the setting of these cements involves neutralization of the polyacid by the basic glass and results in the formation of an ionically cross-linked polyacrylate matrix. Initially, all of the fluoride is in the glass, but during the course of cement formation, fluoride ions are released into the aqueous acid phase and become trapped in the hardening gel matrix. Once the cement has set, the fluoride released may originate from the remaining fluoride glass, the silica gel phase, the polysalt matrix or the pore liquid in which fluoride is loosely bound and free to move?. Moreover, the erosion of GIC in an acidic environment increases the release of fluoride, which induces the formation of an acid-resistant, radiopaque, hypermineralized layer around the restorations ${ }^{27}$.

RMGICs consist substantially of GIC components (water-soluble polymeric acid, ion-leachable glass and water) together with methacrylate monomers and their associated initiation systems. These hybrid materials set partially by means of an acid-base reaction and partially by means of a polymerization reaction that is initiated by photochemical and/or chemical generation of free radicals. The action of 2-hydroxyethyl methacrylate (HEMA) as a cosolvent for organic and aqueous components affects the GIC setting reaction because ions are reluctant to form in the organic medium. Additionally, organic molecules are known to influence the conformation of the polyacrylic acid molecule 22 . RMGICs have the potential to release fluoride in equivalent amounts to conventional cements, but this capacity may be affected not only by the formation of complex fluoride compounds and their interaction with polyacrylic acid, but also by the type and amount of resin used for the photochemical polymerization reaction ${ }^{30}$.

In this study, under high cariogenic challenge, the ability of Vitremer to inhibit artificial caries development was observed, as dentin microhardness loss was statistically lower in this group than in the control along all distances. However, Vitremer did not inhibit caries development as effectively as Ketac- 
Fil at 100 and $200 \mathrm{~mm}$. The extent of the cariostatic effect provided by Ketac-Fil dropped at $300 \mathrm{~mm}$ and became equivalent to Vitremer. Moreover, at 200 $\mathrm{mm}$ and $300 \mathrm{~mm}$, Vitremer behaved in the same way as Charisma and Dyract, in which fluoride release is expected to be low compared to RMGICs. Hara, et al. ${ }^{13}$ (2002) demonstrated that the extent of cariostatic effects provided by conventional GICs and RMGICs was estimated to be about 300 and $150 \mathrm{~mm}$, respectively, in root dentin.

The polyacid-modified composite resin (Dyract) and the composite resin with fluoride (Charisma) were shown to be ineffective in the inhibition of artificial caries lesions, as both did not differ from the control group $(\mathrm{Z250})$ at all the distances. These results are in agreement with other in vitro studies ${ }^{11,13,28}$. Even though polyacid-modified composite resins have no initial fluoride "burst" effect and release lower amounts of fluoride than RMGICs, some cariostatic effect was expected for Dyract. This material does not contain water in its formulation. With time, water must diffuse from the environment toward the material before the process of glass dissolution and fluoride release can begin ${ }^{17}$. The low concentration of fluoride released by the ion-exchange mechanism and the short-term de/remineralization regimen used in this study could explain why these materials were not able to inhibit caries lesion progression around the restorations.

Obviously, in Charisma, a TEGDMA-Bis-GMA composite containing a Ba-Al-F-silicate glass filler, there is no acid-base reaction. The only source of fluoride comes from the glass filler particles, resulting in a slow diffusive release. Moreover, the polymer composition of Charisma does not contain HEMA, which would increase the hydrophilicity of the matrix and facilitate the transport of water and fluoride ions ${ }^{4}$. Composites have fluoride levels much lower than the levels released from conventional GICs or RMGICs and also somewhat lower than polyacid-modified composite resins $s^{3,30}$.

Under the in vitro simulation of high cariogenic challenge used in this study, the fluoride-containing restorative materials did not completely inhibit dentin microhardness loss around the restorations. As fluoride release from different materials may drop to very low levels after a higher initial release of ions $3,4,30$, fluoridation of restoratives with fluoride gels could be an interesting strategy to maintain increased levels of fluoride in surfaces with a high risk of developing caries. Some guidelines for the use of topical fluoride in high-risk patients are available. In the present study, an intensive therapeutic program was simulated with daily application of fluoride gel for $4 \min ^{6,15,25}$. This could be applied at home using a toothbrush or a custommade tray, or it could be professionally supervised for noncompliant home users.

The interaction of particular interest (restorative system $x$ topical treatment) was not significant at any of the distances studied. Hence, the analysis of the effect of fluoride regimes is valid for all the materials tested. Neutral $2 \% \mathrm{NaF}$ and $1.23 \%$ APF gels promoted a similar protection against the progression of artificial caries lesions on root surfaces. This effect is explained by the capacity of fluoride to precipitate a calcium fluoride-like layer onto tooth surfaces, which serves as a reservoir for fluoride when the $\mathrm{pH}$ drops ${ }^{30}$.

However, in vitro studies have also shown that $1.23 \%$ APF gel is more reactive than $2 \% \mathrm{NaF}$ gel. $\mathrm{CaF}_{2}$ formation increases in acidulate media with a consequent increase in the superficial microhardness and acid-resistance of dental structures ${ }^{23}$. Additionally, the ppmF concentration of APF gel $[12,300 \mathrm{ppm}]$ is higher than that of $2 \%$ $\mathrm{NaF}$ gel $[9,040 \mathrm{ppm}]$, with a higher formation of calcium fluoride-like compounds in the former. The similar cariostatic effects of neutral and acidulated fluoride gels were not expected. It is possible that the acidic $\mathrm{pH}$ of APF gel promoted an initial microhardness loss in root dentin in spite of the higher calcium fluoride-like compound formation.

The ability to carry out experiments under highly controlled conditions represents the major advantage of in vitro experimentation ${ }^{27}$. However, the $\mathrm{pH}$-cycling model used to induce the artificial caries lesions does not take into account the effects of loss of the dentin organic phase during root caries, the effects of vital dentin reactions in vivo or the activity of salivary enzymes, thus limiting its clinical relevance. Nevertheless, the ability to quantify changes in mineral content in response to fluoride-containing materials provided information of value in assessing their potential to inhibit root caries $^{2,23,28}$.

In vitro models for caries induction on root dentin can cause superficial erosions that complicate microhardness analysis. Hara, et al. ${ }^{11}$ (2002) suggested reducing the number of de/ remineralization cycles and the time of immersion in the demineralizing solution in order to avoid superficial dentin erosion. In the present study, the model proposed by Featherstone, et al. ${ }^{9}$ (1986) and modified by Serra and Cury ${ }^{26}$ (1992) was adjusted to make it suitable for the microhardness test. Hence, the specimens were immersed in remineralizing solution for $24 \mathrm{~h}$ prior to submission to three cycles of de/remineralization.

The Knoop microhardness value evaluates mineral gain and loss over the course of the de/ remineralization process, taking into account the organic properties of the root dentin. This is an advantage over other methods like microradiography that quantify the mineral content of dentin and exclude the influence of the collagen matrix $^{11-13}$. However, dentin is more porous and less mineralized than enamel, especially after multiple demineralizing cycles, confounding microhardness measurements. The lack of indentation uniformity can also compromise the precision of microhardness 
measures. Hence, to minimize the effects of the dentin substrate on surface microhardness, a Knoop diamond with a $5 \mathrm{~g}$ static load was applied for $30 s^{1}$ to imprint 9 initial and 9 final indentations on a representative circular area of dentin around the restoration.

\section{CONCLUSIONS}

Under the conditions of this in vitro study, it was possible to conclude that fluoride-containing restorative materials as well as fluoride gel application inhibit the progression of caries-like lesions adjacent to restorations, but are not able to prevent the formation of the lesion. Conventional GICs and RMGICs reduced the microhardness loss related to artificial caries and could be recommended for root caries control, primarily in high-risk patients. The use of neutral or acidulate fluoride gels may benefit these patients, although the effects associated with restorative materials have not been demonstrated.

\section{ACKNOWLEDGEMENTS}

This research study was based on a thesis submitted to the Federal University of Minas Gerais in partial fulfillment of the requirements for granting a MS degree, and was supported by a grant-in-aid for scientific research from FAPEMIG (Grant \#CDS79/2003) and PRPq/UFMG.

\section{REFERENCES}

1- American Society for Testing and Materials (ASTM). Annual book of ASTM standards. Norm E384-99: Standard test method for microindentation hardness of materials. Philadelphia: ASTM; 1999.

2- Arends J, Ruben JL, Christoffersen J, Jongebloed WL, Zuidgeest TGM. Remineralization of human dentine in vitro. Caries Res. $1990 ; 24: 432-5$.

3- Can-Karabulut DC, Batmaz I, Solak H, Tastekin M. Linear regression modeling to compare fluoride release profiles of various restorative materials. Dent Mater. 2007;23:1057-65.

4- Chan WD, Yang L, Wan W, Rizkalla AS. Fluoride release from dental cements and composites: a mechanistic study. Dent Mater. 2006;22:366-73.

5- Cury JA, Tenuta LMA. Enamel remineralization: controlling the caries disease or treating early caries lesions? Braz Oral Res. 2009;23(Sp. Issue 1):23-30.

6- Delbem ACB, Brighenti $F L$, Vieira $A E M$, Cury JA. In vitro comparison of the cariostatic effect between topical application of fluoride gels and fluoride toothpaste. J Appl Oral Sci. 2004; 12:121-6.

7- Dhondt CL, De Maeyer EA, Verbeek RM. Fluoride release from glass ionomer activated with fluoride solutions. J Dent Res. 2001;80:1402-6.
8- Donovan T. Critical appraisal: Protocol for the prevention and management of root caries. J Esthet Restor Dentistry. 2008;20:405-11.

9- Featherstone JDB, O'Reilly MM, Shariati M, Brugler S. Enhancement of remineralization in vitro and in vivo. In: Leach $\mathrm{SA}$. Factors relating to demineralization and remineralization of the teeth. Oxford: IRL Press; 1986. p. 23-4.

10- Gonzalez Ede H, Yap AU, Hsu SC. Demineralization inhibition of direct tooth-colored restorative materials. Oper Dent. 2004;29:578-85.

11- Hara AT, Magalhães CS, Serra MC, Rodrigues AL Jr. Cariostatic effect of fluoride-containing restorative systems associated with dentifrices on root dentin. J Dent. 2002;30:205-12.

12- Hara AT, Queiroz CS, Freitas PM, Giannini M, Serra MC, Cury JA. Fluoride release and secondary caries inhibition by adhesive systems on root dentin. Eur J Oral Sci. 2005;113:245-50.

13- Hara AT, Turssi CP, Serra MC, Nogueira MCS. Extent of the cariostatic effect on root dentin provided by fluoride-containing restorative materials. Oper Dent. 2002;27:480-7.

14- Heijnsbroek M, Paraskevas S, Van der Weijden GA. Fluoride interventions for root caries: a review. Oral Health Prev Dent. 2007;2:145-52

15- Jardim JJ, Pagot MA, Maltz M. Artificial enamel dental caries treated with different topical fluoride regimes: an in situ study. J Dent. 2008; 36:396-401.

16- Kassab MM, Cohen RE. The etiology and prevalence of gingival recession. J Am Dent Assoc. 2003;134;220-5.

17- Meyer JM, Cattani-Lorente MA, Dupuis V. Compomers: between glass-ionomer cements and composites. Biomaterials.1998;19:529-39.

18- Mjör IA. Clinical diagnosis of recurrent caries. J Am Dent Assoc. 2005;136:1426-33.

19- Mjör IA. Secondary caries: a literature review with case reports. Quintessence Int. 2000;31:165-79.

20- Montgomery DC. Design and analysis of experiments. 3rd ed. New York: Wiley; 1991.

21- Nakajo K, Imazato S, Takahashi Y, Kiba W, Ebisu S, Takahashi N. Fluoride released from glass-ionomer cement is responsible to inhibit the acid production of caries-related oral streptococci. Dent Mater. 2009;25:703-8.

22- Nicholson JW. Chemistry of glass-ionomer cements: a review. Biomaterials. 1998;19:485-94.

23- Nyvad B, Ten Cate JM, Fejerskov O. Arrest of root surface caries in situ. J Dent Res. 1997;76:1845-53.

24- Okuyama K, Nakata T, Pereira PN, Kawamoto C, Komatsu H, Sano $H$. Prevention of artificial caries: effect of bonding agent, resin composite and topical fluoride application. Oper Dent. 2006;31:135-42.

25- Pedrini D, Delbem ACB, França JGM, Machado Tde M. Fluoride release by restorative materials before and after a topical application of fluoride gel. Pesqui Odontol Bras. 2003;17:137-41. 26- Serra MC, Cury JA. The in vitro effects of glass-ionomer cement restoration on enamel subjected to a demineralization and remineralization model. Quintessence Int. 1992;23:143-7.

27- Ten Cate JM, Buijs MJ, Damen JJM. The effects of GIC restorations on enamel and dentin demineralization and remineralization. Adv Dent Res. 1995;9:384-8.

28- Torii $Y$, Itota $T$, Okamoto $M$, Nakabo $S$, Nagamine M, Inoue $\mathrm{K}$. Inhibition of artificial secondary caries in root by fluoridereleasing restorative materials. Oper Dent. 2001;26:36-43.

29- Weidlich P, Miranda LA, Maltz M, Samuel SM. Fluoride release and uptake from glass-ionomer cements and composite resins. Braz Dent J. 2000;11:89-96.

30- Wiegand A, Buchalla W, Attin T. Review on fluoride-releasing restorative materials - fluoride release and uptake characteristics, antibacterial activity and influence on caries formation. Dent Mater. $2007 ; 23: 343-62$. 